\title{
Addressing America: George Washington's Farewell and the Making of National Culture, Politics, and Diplomacy, 1796-1852
}

Review Number: 1908

Publish date: Thursday, 17 March, 2016

Author: Jeffrey J. Malanson

ISBN: 978-1-60635-251-9

Date of Publication: 2015

Price: $£ 35.29$

Pages: 288pp.

Publisher: Kent State University Press

Publisher url: http://www.kentstateuniversitypress.com/2014/addressing-america/

Place of Publication: Kent, $\mathrm{OH}$

Reviewer: Stephen Tuffnell

In February 1862, the Pennsylvanian Republican John W. Forney read aloud George Washington's 'Farewell Address' on the Senate Floor. The occasion? It was the 130th anniversary of the first President's birth. Each year the United States Senate continues to observe Washington's Birthday in the same manner, alternating between speakers from each party. In 2012, this custom was observed for the 150th time, but the reader, Sen. Jeanne Shaheen (D-NH), cut a lonely figure - not a single one of her colleagues was in attendance (with the exception of Sen. Richard Blumenthal, obliged to be present as the Senate Pro Tempore). In the same week, the House opened a committee of its own: 'Honoring George Washington's Legacy: Does America Need a Reminder?' Perhaps the North Wing of the Capitol should have been sent a memo too.

This was not always the case. In a concise and lively study, Jeffrey Malanson recaptures the fierce political debates surrounding the evolving framework provided by Washington's valedictory address for understanding domestic politics and international relations in the United States. As a caution against the 'common and continual mischiefs of the spirit of party' and a nuanced forumla advocating a cautious approach to foreign affairs, the Farewell Address is a familiar and frequently cited document. As the flexible instrument through which citizens in the early republic understood and reformulated the role of the fragile Union in the community of nations, it is much less appreciated. Addressing America is a fresh consideration of this totemic document that successfully opens out its wider importance to the domestic and foreign policies of the United States.

The central theme of Addressing America is of the continuous evolution of the Farewell Address. For Malanson, the Farewell Address is the compass with which American statesmen and citizens navigated the problems of independence and nation-building. 'People throughout the nation', writes the author, 'derived their understanding of the development of the United States, its relationship with the wider world, and ultimately its responsibilities on the global stage from Washington's Farewell Address' (p. 4). Closely argued and deeply researched, Addressing America tracks the reinvention of Washington's Farewell across the various wars, crises, and imperial ventures of the United States. 'Popular reverence for Washington and his principles ensured that they would continue to guide U.S. Presidents and policy makers', Malanson 
writes, and demonstrates admirably the centrality of Washington's message to the major events of antebellum foreign affairs (p. 4).

Addressing America is neither a standard diplomatic or intellectual history of American statecraft. In To The Farewell Address, Felix Gilbert's masterly account of the intellectual origins of Washingtonian statecraft, the integration of realism and idealism 'constitutes the distinguishing feature of the Farewell Address'.(1) Malanson helpfully moves us beyond this dialectic to the manifold processes, ideas, and international contexts that contributed to the Address' evolution. Similarly, Malanson shifts the focus from the intellectual inheritance of enlightenment political philosophy embodied in Alexander Hamilton's penmanship of the message to the volatile realm of public debate where the Address was reformulated and given centre stage in the discussion of the United States' role in international affairs; and away from the original authors to its subsequent editors in the State Department, as US statesmen attempted to navigate the unfolding dramas of independence and nation-building.

Although it was Washington's Farewell, therefore, he was powerless to control its meaning. The most enduring transformation came soon after its inception. In his first inaugural address, Thomas Jefferson did more than any subsequent statesman to fix the meaning of the Farewell Address in the minds of the American public. Standing before Congress, Jefferson sought to lay out the 'essential principles of our Government' and, in a famous formulation, promised 'peace, commerce, and honest friendship with all nations, entangling alliances with none'. In an ironic twist, Malanson notes, Jefferson had 'oversimplified' the Farewell Address' 'pragmatic and flexible maxims for the conduct of American foreign relations into a rigid and permanent declaration of virtual isolation from the rest of the world' (p. 34). Jefferson's phraseology echoed Washington's (though they were separated by a great distance in meaning) and intersected with the powerful myth-making that greeted Washington's death in December 1799. In the public mourning that followed, Washington was elevated to the pantheon of American revolutionary heroes and the Address to holy writ. Over time, as the distinction between Jefferson's phrase and Washington's maxims blurred, the precept of 'entangling alliances with none' crystallised into foreign policy principle.

For a fragile post-colonial republic, vulnerable along its exposed Atlantic seaboard; bound by European Empires, north and south; and pressed in the west by powerful Indian confederacies, the question of independence loomed large. Washington's Address therefore sprang to prominence in the War of 1812 commonly viewed as the Union's second War for Independence from Britain. Malanson deftly traces the Federalist resurgence through the rapid spread of Washington Benevolent Societies, equivalent to, though less successful than, the Democratic Republican Societies that swept Jefferson to power in 1800. By 1812, these societies could be found in 11 states, and four years later numbered more than 200 (p. 51). The societies attempted to wrestle the Address' meaning back from the Jeffersonian Republicans, blaming the war on their abandonment of Washington's wise counsel. Not content to fight a prolonged and brutal conflict along the border with Upper Canada, Americans engaged in a partisan battle over the meaning of the revolution and how best to secure independence. Malanson clearly evokes the partisan utility of Washington's Address for the surging Federalists while the war endured, less clear is its utility to those who invoked it as a practical guide for navigating the imperial predicaments the republic encountered and especially for ending the conflict. 
The most far-reaching transformation of the Address came from John Quincy Adams. A flexible and expansive thinker, Adams sought freedom of action for American foreign policy across the western hemisphere - rather than in terms of the Old World/New World division that stood at the heart of the Founding generation's thought. Malanson lucidly traces Adams' attempts to eliminate European influence in the Americas and preserve future opportunities for westward expansion. To do so, Monroe's Secretary of State expanded the principles of separate spheres and non-colonization - most famously articulated in the Monroe Doctrine. This was dramatic evolution of the Farewell Address: 'Adams converted Washington's moderate cautions to Americans themselves into a warning to European rulers to pursue their own policy of neutrality towards the Americas' (p. 82). This was also an imperial doctrine. Both principles worked on the assumption that European colonization would give way to US dominance of the Americas.

As President, Adams sought to extend these principles further at the Panama Congress convened by Simón Bolivar in 1826. For Adams, the Congress was 'both a venue at which to clarify and reinforce America's continued adherence to Washington's recently expanded principles and an opportunity to have those principles accepted internationally' (p. 84). If Adams was a clear-headed thinker, he was a poor communicator and badly mismanaged the Congressional debate that followed (pp. 102-11), which resulted in a three week distraction that ultimately doomed the mission. Badly damaged by the 'corrupt bargain' that had propelled him to the Presidency in 1824, Adams was a divisive figure and presided over the emergence of the Second Party System. Elevated by Adams' rapidly coalescing domestic opponents to partisan principle, 'entangling alliances with none' dominated Congressional and public discussion. For their part, Adams' supporters failed to make a principled defence of the President's reinterpretation of the Farewell Address. The Panama Debate, Malanson argues, was the 'day of reckoning for these two increasingly divergent views of the Farewell Address' (p. 98). Jefferson's inflexible isolation easily won the day and the US Ministers never made it to Panama.

Not that Malanson would have us believe that American statesmen were guided solely by ideology. The statesmen in the pages of Addressing America are realists, opportunists, and geostrategic thinkers. This is most evident in Malanson's consideration of the presidencies of Tyler and Polk (chapter five). In his pursuit of Texas, President John Tyler 'became willing to abandon Washington's Farewell Address and pervert the doctrine of two spheres' (p. 128). For His Accidency and Young Hickory, it was not the Farewell Address that proved the most flexible instrument of empire-building but the Monroe Doctrine. In the process, the pair 'moved the United States away from strict adherence to the maxims of Washington's Farewell Address' (p. 130) - or more properly, away from the fixed meaning it had acquired at the hands of Jefferson. As the sectional crisis over slavery deepened thanks to Polk's imperial conquest of Mexico, 'unionist concerns and a growing ambivalence about America's foreign-policy principles' increasingly influenced popular interpretations of Washington's Address. Indeed, Malanson argues, while the Address 'remained an enduring statement of American ideals' for others it was increasingly 'a relic' (p. 146) - or in Abel Upshur's formulation while it had been 'suited to our infant conditions ... we should remember that the infant of that day has grown into a powerful commercial nation, whose interests are diffused over every quarter of the globe' (p. 144). As Upshur's words suggest, the nationalist language of Manifest Destiny arguably overwhelmed the moderation of the Address, a fuller consideration of which would be helpful in setting the discussion of the Farewell Address in its wider context.

If pressed to select the document that loomed largest in the minds of American statesmen, most historians of antebellum foreign policy would not be as assured as Malanson in asserting that 'the Address remained the most important document in shaping Americans' understandings of their foreign-policy principles and the relationship of their nation with the rest of the world' (p. 181). In historiographic terms, Addressing America complements Jay Sexton's Monroe Doctrine (2011), David Hendrickson's fresh interpretation of the concept of 'Union' in 19th-century American statecraft, and, to a lesser extent, David Armitage's study of the Declaration of Independence.(2) All of these works highlight the flexibility of the texts available to American statesmen when navigating the United States' interaction with foreign nations. Addressing America expertly recaptures the Farewell Address's place amongst these foundational texts and highlights its 
centrality to the formulation and transformation of their key components. Methodologically speaking, however, isolating the Address poses some challenges. Malanson is on firm ground when it comes to demonstrating the centrality of the Address to the occupants of the State Department and Executive. But this reviewer was left intrigued as to where exactly the Farewell Address stood in the political vocabulary of US policy and opinion makers. Was it a catalyst in the public celebrations and events Malanson highlights, or something appealed to from habit rather than principle? Does its invocation reveal more about the need to invoke Washington's support than the specifics of the Address itself? Was it a stable touchstone for political commentators and partisan stump speakers, or only appealed to selectively?

To take one instance, how did the Address interact with the pervasive Anglophobia that, as recently demonstrated so admirably by Sam Haynes, infused all aspects of antebellum America?(3) The jabs and feints with which the Farewell Address equipped orators seem technical and gentile in comparison to the bare-knuckle brawling of Anglophobes. Or was it that the subtlety of Washington's Address, with its emphasis on cautious engagement with foreign powers, provided the key to navigating the tightrope between compromise and competition with the Union's greatest threat? Bound up in this is another, more fundamental question. To what extent was the debate over the meaning of Washington's Address a sub-plot of the wider contest over the meanings of independence and how best to recapture the spirit of the Revolution?

These thoughts are not intended as broadsides against an invaluable study of Washington's most quoted, but as Malanson shows, most misunderstood document. Yet they do indicate some recent developments in the field of antebellum foreign policy. First, scholarship on American foreign relations in the antebellum era is passing through a particularly fertile period since Kinley Brauer famously declared it 'the Great American desert' of American historiography in 1989.(4) Second, these questions emphasise that in this historiography, the focus of recent work has been on the wider cultural context in which foreign affairs were shaped rather than on the high political authors of policy who feature most prominently in Addressing America. The result has been a growing and diversifying chorus of voices - domestic opponents, newspaper columns, public orations, popular meetings, party gatherings, Congress, and the Cabinet - engaged in the creation of foreign policy. Addressing America is an engaging contribution to this discussion and a reminder that diplomatic historians are now central, and indispensable, to the recent historiography on the international connections of revolutionary and early national America.(5)

Whether as the framework for understanding the republic's foreign policy principles or as the compass for navigating turbulent relationships to foreign states, Addressing America makes a persuasive case that Washington's valedictory advice proved a resilient document for Antebellum Americans. Concise and closely argued, Malanson's volume will be vital reading for those interested in American conceptions of their republic's role in international affairs.

\section{Notes}

1. Felix Gilbert, To the Farewell Address: Ideas of Early American Foreign Policy (Princeton, NJ, 1961). Back to (1)

2. Jay Sexton, The Monroe Doctrine: Empire and Nation in Nineteenth-Century America (New York, NY, 2011); David C. Hendrickson, Union, Nation, or Empire: The American Debate over International Relations (Lawrence, KS, 2009); David Armitage, The Declaration of Independence: A Global History (Cambridge, MA and London, 2007).Back to (2)

3. Sam Haynes, Unfinished Revolution: The Early American Republic in a British World (Charlottesville, VA and London, 2010).Back to (3)

4. Kinley Brauer, 'The great American desert revisited: recent literature and prospects for the study of American foreign relations, 1815-1861', Diplomatic History, 13, 3 (1989), 395-417.Back to (4)

5. This is a turnaround from almost 20 years ago, when Peter S. Onuf called for diplomatic historians to break out of the bounds of narrowly defined diplomatic history and play their part in the revision of the period, Peter S. Onuf, 'A declaration of independence for diplomatic historians', Diplomatic History, 
22, 1 (Winter 1998), 71-83.Back to (5)

Source URL:https://reviews.history.ac.uk/review/1908

Links

[1] https://reviews.history.ac.uk/item/148982 